\title{
PERANCANGAN LOGO BRAND IDENTITY SANDPIPER SEBAGAI UPAYA PENINGKATAN BRAND
}

\author{
Dion Eko Valentino \\ Politeknik LP3I Kampus K. Pekanbaru \\ Email: dion.plb@gmail.com
}

\begin{abstract}
Abstrak: Menurut Sularko dalam bukunya yang berjudul "How Do They Think," mengemukakan bahwa logo atau corporate identity atau Brand identity adalah sebuah tanda yang secara langsung tidak menjual, tetapi memberi suatu identitas yang pada akhirnya sebagai alat pemasaran yang signifikan, bahwa logo mampu membantu membedakan suatu produk atau jasa dari kompetitornya. Tujuan dari perancangan logo ini adalah sebagai upaya untuk membangun citra Brand Sandpiper agar dapat lebih dikenal dan diingat oleh konsumen. Dalam perancangan ini bentuk logo yang dibuat disesuaikan dengan konsep produk yang dijual kepada masyarakat serta perwarnaan yang contrast sebagai identitas dari perusahaan Sandpiper. Selain sebagai identitas perusahaan, logo juga dapat digunakan sebagai media untuk keperluan pemasaran. Makna logo perusahaan Sandpiper didapat dari aspirasi dan konsep yang diberikan oleh perusahaan sebagai representasi dari produk yang mereka jual, sehingga diharapkan jika konsumen yang melihat logo perusahaan akan segera menasfirkan makna dengan produk yang dijual.
\end{abstract}

Kata Kunci: Logo, Brand Identity, Design

\section{Pendahuluan}

Di era persaingan bisnis yang sangat ketat sekarang ini, hampir semua perusahaan berlomba-lomba untuk memasarkan produk yang lebih baik atau yang lebih menarik dari para pesaingnya, yaitu dengan cara menambahkan unsur desain pada produk yang mereka tawarkan. Bermacam - macam cara yang dilakukan perusahaan agar menarik perhatian dari konsumen, salah satu contohnya dengan menambahkan desain kepada bagian-bagian produknya, misalkan pada segi packaging ataupun produk yang berkolaborasikan dengan para penggiat seni terkenal sehingga dapat lebih menarik peminat. Mulai dari perusahaan besar hingga perusahaan kecil mereka menggunakan jasa desain dari para desainer yang mereka rekrut untuk membantu mereka menghasilkan produk yang baik dan menarik di mata konsumen.

Dalam menghasilkan sebuah produk, perusahaan tidak hanya mencari keuntungan atau kemenangan dari persaingan bisnis antar kompetitor, tetapi perusahaan juga ingin menyasar sisi emosional dari penikmat produk, dimana para penikmat produk akan merasakan bahwa produk yang mereka gunakan merupakan perwakilan dari ekspresi diri dan mencerminkan sifat penggunanya. Tahapan untuk dapat menyentuh sisi emosional dari penikmat produk biasanya berawal dari logo perusahaan yang mengeluarkan atau menciptakan produk itu sendiri, kemudian barulah masuk kepada produk yang ditawarkan kepada konsumen.

Logo didalam perusahaan dapat diibaratkan sebagai wajah dari perusahaan itu sendiri. Logo harus mendapatkan perhatian khusus dalam pembuatan konsep dan proses 
penciptaan, sehingga logo bisa menjadi alat pencitraan dari perusahaan. Maka logo tidak dapat diciptakan hanya dengan konsep yang tidak jelas. Sebagai seorang desainer dalam pembuatan logo, wajib melakukan riset dan analisis agar dapat membuat logo yang berkonsep kuat.

Pada tulisan ini penulis akan membahas proses pembuatan logo dari Perusahaan Sandpiper. Teori dari brand atau merek, contohnya brand identity dan brand image. Hal lain juga yang termuat pada tulisan ini adalah contoh-contoh dari perusahaaanperusahaan yang memiliki logo yang berkonsep.

\section{Landasan Teori}

\subsection{Logo}

Logo berasal dari Bahasa Yunani yaitu Logos, yang berarti kata, pikiran, pembicaraan, akal budi. Pada awalnya yang lebih populer adalah istilah logotype, bukan logo. Pertama kali istilah logotype muncul tahun 1810-1840, diartikan sebagai tulisan nama entitas yang didesain secara khusus dengan menggunakan teknik lettering atau memakai jenis huruf tertentu logotype adalah elemen tulisan saja. (Rustan, 2009: 12)

Istilah logotype mengalami perubahan menjadi logo pada tahun 1937. Logo bisa menggunakan elemen apa saja, berupa tulisan, logogram, gambar, ilustrasi, dan lain-lain. Banyak juga yang mengatakan logo adalah elemen gambar/ simbol pada identitas visual. (Rustan, 2009: 13).

Fungsi logo adalah sebagai berikut (Rustan, 2009: 13):

a. Identitas diri. Untuk membedakannya dengan identitas milik orang lain

b. Tanda kepemilikan. Untuk membedakannya dengan milik orang lain

c. Tanda jaminan kualitas

d. Mencegah peniruan/ pembajakan.

Menurut David E Carter, pakar Corporate Identity, dan penulis buku "The Big Book of Logo" jilid 1, 2, dan 3 dari Amerika, pertimbangan-pertimbangan tentang logo yang baik itu harus mencakup beberapa hal sebagai berikut:

a. Original dan distinctive, atau memiliki ciri yang khas, unik, memiliki daya pembeda yang jelas dengan logo lain.

b. Legible, atau memiliki tingkat keterbacaan yang tinggi ketika diaplikasikan ke dalam berbagai ukuran dan media promosi yang berbeda-beda.

c. Simple atau sederhana, artinya mudah ditangkap dan dimengerti dalam waktu yang relatif singkat.

d. Memorable, atau mudah diingat karena keunikannya dalam waktu yang relatif lama.

e. Easy associated with the Company, dimana logo yang baik mudah untuk dihubungkan atau diasosiasikan dengan jenis usaha dan citra suatu perusahaan atau organisasi.

f. Easily adabtable for all graphic media, di sini faktor kemudahan mengaplikasikan (memasang) logo baik yang menyangkut bentuk fisik., warna maupun konfigurasi logo pada berbagai media grafis perlu diperhitungkan pada saat proses pencanangan. Hal itu untuk menghindari kesulitan-kesulitan dalam penerapannya. (Kusrianto, 2006: 234) 
Beberapa hal yang harus diperhatikan dalam membuat logo antara lain (Safanayong, 2006) :

a. Tipografi. Cukup banyak logo yang berhasil hanya dengan menggunakan tipografi. Entah itu serif/ sans serif atau jenis font lainnya. Penggunaan tipografi dapat memberikan semacam "emosi" kepada mereka yang melihatnya. Setelah kita menemukan jenis tipografi yang cocok dengan apa yang ingin kita wakili, barulah kita masuk pada masalah warna.

b. Warna. Warna adalah salah satu hal yang sangat krusial dalam pembuatan logo, karena apabila warna yang kita gunakan salah, bisa-bisa pesan dan emosi yang kita ingin sampaikan kepada masyarakat menjadi kacau dan rancu. Warna logo sebaiknya yang sederhana dan mudah diingat, tapi tetap bisa memberikan ekspresi langsung kepada masyarakat atau konsumen. Selain itu, penggunaan warna yang sederhana dapat menghemat biaya produksi.

c. Bentuk. Banyak sekali logo yang bentuknya unik. Akan tetapi perhatikanlah bentuk logo yang ingin kita desain, karena setiap bentuk, baik lurus, siku, bundar, dan lainnya memiliki arti sendiri; bisa pasif, bisa aktif. Misalnya klien kita menginginkan logo untuk sebuah produk sabun, sebaiknya hindari logo dengan bentuk yang keras dan siku

d. Keseimbangan. Keseimbangan di sini maksudnya adalah mencari atau menemukan seberapa baik logo yang kita buat. Apabila kita sudah berhasil menciptakan sebuah logo, cobalah untuk memutar atau membolak-balik logo tersebut untuk mendapatkan kemungkinan-kemungkinan lain yang bisa membuat logo lebih berkembang.

e. Selera. Hal ini juga cukup menentukan dalam pembuatan sebuah logo mengingat selera setiap orang berbeda-beda dan sangat subyektif.

f. Riset. Aspek ini adalah aspek yang paling penting dalam membuat sebuah logo. Ini adalah jawaban kunci dalam membuat sebuah logo yang baik. Riset disini tentunya bukan riset yang hanya dilakukan dalam waktu 1-2 jam, melainkan riset secara penuh. Kita juga harus mengerti perspektif dari pemesan logo. Berbicara dengan klien, orang-orang yang berada di perusahaan tersebut, klien dari perusahaan tersebut, para distributor, kemudian mencari data-data yang akurat tentang perusahaan tersebut, barulah mulai membuat logonya.

g. Opini, tidak ada salahnya tanyakan juga pandangan, kritik, dan masukan dari orang lain.

\subsection{Brand}

Dalam bukunya "Principle of Marketing" (2012) Kotler dan Amstrong menjelaskan brand adalah sebuah nama, istilah, tanda, simbol, atau desain atau sebuah kombinasi di antaranya, yang bertujuan untuk mengidentifikasikan barang atau jasa yang dihasilkan oleh produsen. Menurut mereka merek / brand akan memudahkan konsumen dalam mengidentifikasi produk-produk yang ada di pasar, mengidentifikasi produk-produk mana yang memiliki manfaat lebih, atau produk-produk mana yang sesuai dengan selera konsumen. Ditambah merek juga menyatakan sesuatu tentang konsistensi dan kualitas. Artinya bila kualitas dan konsistensi suatu merek itu bagus, maka akan sangat mudah diterima oleh konsumen.

Menurut Aaker (1997) brand adalah nama atau simbol yang besifat membedakan dengan maksud mengidentifikasikan barang atau jasa dari seorang atau 
kelompok penjual tertentu sehingga membedakannya dari produk lain yang dihasilkan oleh para kompetitor. Membedakan disini bisa berarti dari segi logo, cap, nama, kemasan dll. Produk lain bisa berupa barang-barang maupun jasa.

Alina Wheeler (2006) menjelaskan bahwa: "A brand is the nucleus of sales and marketing activities, generating increased awareness and loyalty, when managed strategically".

Merek adalah nucleus (inti) dari sales (penjualan) dan kegiatan pemasaran, menghasilkan peningkatan awareness (kesadaran) dan loyalty (loyalitas) apabila dikelola secara strategis.

Terdapat enam tingkat pengertian merek menurut Surachman $(2008 ; 3)$, yaitu:

a. Atribut

Setiap merek memiliki atribut. Atribut ini perlu dikelola dan diciptakan agar konsumen dapat mengetahui dengan pasti atribut-atribut apa saja yang terdapat dalam suatu merek.

b. Manfaat

Merek sebagai atribut mempunyai dua manfaat yaitu manfaat emosional dan manfaat fungsional. Atribut "mudah didapat" dapat diterjemahkan sebagai manfaat fungsional. Atribut "mahal" dapat diterjemahkan sebagai manfaat emosional.

c. Nilai

Merek juga harus menyatakan nilai bagi produsennya. Sebagai contoh: Produsen sepatu Adidas merupakan produsen yang disukai masyarakat didunia. Hal ini menjadi bukti bahwa Adidas memiliki nilai yang tinggi di masyarakat.

d. Budaya

Merek mewakili budaya tertentu.

e. Kepribadian

Merek dapat mencerminkan kepribadian tertentu.

f. Pemakai

Merek menunjukan jenis konsumen yang membeli atau memakai merek tersebut, maka dari itu para penjual menggunakan analogi untuk dapat memasarkan mereknya kepada konsumen.

Menurut Tjiptono (2002:104) brand itu sendiri dapat digunakan untuk beberapa tujuan diantaranya :

Sebagai identitas, yang bermanfaat dalam differensiasi atau membedakan produk suatu perusahaan dengan produk pesaingnya. Ini akan memudahkan konsumen untuk mengenalinya pada saat Menurut Tjiptono (2002:104) brand itu sendiri dapat digunakan untuk beberapa tujuan diantaranya :

a. Berbelanja.

b. Alat promosi, yaitu sebagai daya tarik produk.

c. Untuk membina citra, yaitu dengan memberikan keyakinan, jaminan kualitas serta pretise tertentu pada konsumen.

d. Untuk mengendalikan pasar.

Menurut Durianto (2001:2) merek menjadi sangat penting saat ini karena beberapa faktor, seperti:

a. Emosi konsumen terkadang turun naik. Merek mampu membuat janji emosi menjadi konsisten dan stabil. 
b. Merek mampu menembus setiap pagar budaya dan pasar. Bisa dilihat bahwa suatu merek yang kuat mampu diterima di seluruh dunia dan budaya.

c. Merek mampu menciptakan komunikasi interaksi dengan konsumen. Semakin kuat suatu merek, makin kuat pula interaksinya dengan konsumen dan makin banyak asosiasi merek yang terbentuk dalam merek tersebut. Jika asosiasi merek yang terbentuk memiliki kualitas dan kuantitas yang kuat, potensi ini akan meningkatkan citra merek.

d. Merek sangat berpengaruh dalam membentuk perilaku konsumen. Merek yang kuat akan sanggup merubah perilaku konsumen

Menurut Soehadi (2005), kekuatan suatu merek (brand equity) dapat diukur berdasarkan 7 indikator, yaitu:

a. Leadership: kemampuan untuk mempengaruhi pasar, baik harga maupun atribut nonharga.

b. Stability: kemampuan untuk mempertahankan loyalitas pelanggan.

c. Market: kekuatan merek untuk meningkatkan kinerja toko atau distributor.

d. Internationality: kemampuan merek untuk keluar dari area geografisnya atau masuk ke negara atau daerah lain.

e. Trend: merek menjadi semakin penting dalam industri.

f. Support: besarnya dana yang dikeluarkan untuk mengkomunikasikan merek.

g. Protection: merek tersebut mempunyai legalitas

\subsection{Brand Identity}

Menurut David A. Aaker dan Erich (2002:43) brand identity terbentuk dari dua puluh dimensi yang digabung menjadi empat, yaitu brand as product, brand as organization, brand as person, dan brand as symbol.

a. Brand as Product

Asosiasi yang berhubungan dengan produk tetap penting sebagai bagian dari identitas merek, atribut secara langsung berhubungan dengan pembelian atau pengggunaan produk yang dapat memberikan keuntungan fungsional maupun emosional bagi konsumen. Atribut yang berhubungan dengan sebuah produk dapat menciptakan proporsi nilai melalui penawaran yang lebih baik.

\section{b. Brand as Organization}

Brand as organization memfokuskan pandangannya pada attributes of the organization dari pada terhadap produk atau jasa. Organization attributes meliputi suatu inovasi, peningkatan kualitas, perhatian terhadap lingkungan yang diciptakan oleh orang, budaya, nilai maupun program dari perusahaan.

c. Brand as Person

Brand as person memberikan kesan yang lebih menarik terhadap brand identity, karena brand as person diasumsikan seperti halnya manusia. Pribadi merek dapat menciptakan merek yang kuat dengan berbagai cara. Pertama, membantu menciptakan manfaat ekspresi diri sebagai sarana konsumen untuk mengeksperesikan kepribadiannya. Kedua, sifat-sifat manusiawi mempengaruhi hubungan antar konsumen dan merek. Ketiga, pribadi merek dapat 
mengkomunikasikan atribut produk dan memberikan sumbangan bagi manfaat fungsional.

\section{d. Brand as Symbol}

Simbol yang kuat dapat memberikan keeratan dan struktur bagi sebuah identitas serta mempermudah produk untuk dikenal dan diingat. Kehadiran simbol dapat merupakan kunci pengembangan produk untuk dikenal dan diingat. Kehadiran simbol dapat merupakan kunci pengembangan merek. Simbol terdiri atas citra visual, metafora, dan kebesaran merek. Simbol yang melibatkan pencitraan visual memudahkan untuk diingat dan memiliki kekuatan. Simbol akan sangat bermakna jika bermetafora dengan karakteristik simbol yang menampilkan manfaat fungsional, emosional, atau ekspresi diri. Simbol yang kuat akan membantu strategi merek. Apabila simbol yang digunakan perusahaan sesuai dengan karakteristik dari pelanggan maka akan dapat memberikan nilai functional dan emotional. Identitas dari perusahaan seperti slogan, simbol, jingle, dan lain-lain harus dapat menciptakan pengalaman sehingga akan dapat mempermudah dalam pembentukan brand identity.

Identitas merek adalah seperangkat asosiasi merek yang unik identitas merek adalah seperangkat asosiasi merek yang unik yang diciptakan oleh para penyusun strategi merek. Asosiasi-asosiasi ini mencerminkan kedudukan suatu merek dan merupakan suatu janji kepada pelanggan dari anggota organisasi. Identitas merek akan membantu kemantapan hubungan diantara merek dan pelanggan melalui proposisi nilai yang melibatkan manfaat fungsional, manfaat emosional atau ekspresi diri. (Kotler \& Keller,2006:261)

Reid (2006) dalam Beatrice, Diah dan Rizky (2014 : 2) mengemukakan beberapa langkah dalam membentuk brand identity, yaitu sebagai berikut :

a. Membuat rancangan bisnis, visi dan misi, dan beberapa hal yang menunjukkan bahwa merek tersebut berbeda dengan lainnya.

b. Melakukan survey atau wawancara kepada masyarakat mengenai persepsi mereka terhadap suatu merek.

c. Melakukan penelitian terhadap merek pesaing yang memiliki kemiripan

d. Membuat logo, tagline, dan hal-hal lainnya yang mendukung dalam pembentukan brand identity.

e. Melakukan survey secara berkala mengenai persepsi masyarakat terhadap merek tersebut.

\subsection{Sejarah Perusahaan Sandpiper}

Sandpiper merupakan perusahaan yang didirikan pada tahun 2017 tepatnya pada bulan Oktober oleh seorang pemain basket professional Indonesia. Lahirnya perusahaan ini didasari pada trend yang sedang berkembang pada saat itu, yaitu trend dimana para olahragawan dari seluruh penjuru dunia menggunakan sandal dari merek-merek ternama dunia. Berangkat dari keinginan memajukan dan memperkenalkan brand lokal indonesia yang dapat bersaing dengan merek-merek asing yang ternama, maka lahirlah brand Sandpiper.

Hasil dari wawancara yang didapat penulis dari pembicaraan dengan pemilik perusahaan, bahwa perusahaan ini didirikan dengan nama Sandpiper yaitu mengadaptasi dari suatu 
jenis burung yang bernama sandpiper, dimana burung tersebut merupakan burung yang habitat hidupnya berada di laut dan selalu dekat dengan air. Selain itu pula burung ini merupakan burung yang kecil dengan kemampuan terbang melawan angin di pantai maupun laut.

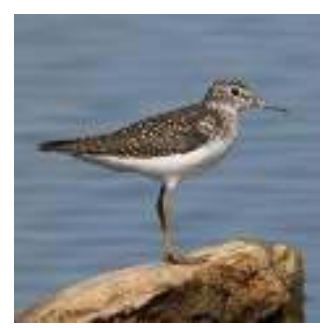

Gambar 1. Burung Sandpiper

(sumber: www.tnwatchablewildlife.org)

\section{Rumusan Masalah}

Rumusan masalah pada penelitian ini adalah bagaimana cara perancangan logo brand pada perusahaan Sandpiper. Hal ini penulis angkat karena perusahaan ini belum memiliki logo yang dirancang berdasarkan teori-teori logo oleh para ahli. Gagasan logo yang diberikan kepada penulis oleh pemilik perusahaan hanya berdasarkan pada kesukaan saja dan mengikuti referensi dari logo perusahaan lainnya, maka berangkat dari permasalahan tersebut, penulis berniat untuk membantu perancangan logo perusahaan dengan memiliki dasar konsep yang jelas.

\section{Manfaat Perancangan}

Manfaat didapat dari perancangan dan penelitian ini diharapkan dapat menambah wawasan dan pengetahuan bagi pembaca dalam bidang perancangan brand, selain itu juga diharapkan dengan adanya penelitian ini khalayak luas dapat mengetahui bagaimana perancangan sebuah brand, serta dapat menjadi referensi brand lokal Sandpiper yang bergerak dalam bidang usaha sandal.

Manfaat penelitian ini juga dapat digunakan sebagai referensi bagi peneliti lain dalam melakukan penelitian dengan tema yang sama terhadap perusahaan lain. Selain itu juga penelitian ini diharapkan menjadi sumber informasi baik dari segi teori, segi perancangan, dan hal yang lainnya sebagaimana disajikan dalam penelitian ini.

Hasil dari penelitian ini diharapkan dapat diaplikasikan khususnya kepada brand Sandpiper serta bisa juga diaplikasikan kepada brand lainya, sehingga dapat membangun brand lokal indonesia yang nantinya bisa bersaing dengan kompetitor lokal lainnya atau bahkan bersaing dengan kompetitor brand dari luar negeri.

\section{Metode Penelitian}

Metode penelitian yang dilakukan penulis antara lain dengan wawancara, studi literatur, dan studi lapangan. Wawancara dilakukan oleh penulis kepada stakeholder dari perusahaan Sandpiper dan para pengguna produk dari brand lain. Hal ini dilakukan dimana salah satunya agar penulis dapat mengetahui keinginan serta masukan baik dari 
sisi internal maupun sisi eksternal. Kemudian pendekatan dengan studi literatur dengan mencari sumber-sumber informasi atau data terkait yang mendukung dalam penulisan dan perancangan logo baik melalui buku atau media cetak, serta dari media elektronik. Studi lapangan dilakukan dengan melakukan pengamatan serta analisis terhadap brand kompetitor.

\section{Hasil Perancangan}

Dalam perancangan logo ini penulis mengunakan beberapa software pengolah gambar, yaitu adobe photoshop cc 2018, adobe illustrator cc 2018 dan acdsee 10 edit image. Berdasarkan hasil wawancara dengan pemilik perusahaan, maka penulis menjabarkan keinginan pemilik perusahaan dalam perancangan logo perusahaan dengan menggunakan unsur logo dan warna. Logo yang digunakan dalam perusahaan Sandpiper meliputi logotype Sandpiper dan logo burung. Logotype dibuat oleh penulis dengan warna hitam yaitu warna monochrome tetapi pada huruf A diberikan warna merah, dimana tujuannya adalah pembaca atau konsumen terfokuskan kepada logotype tersebut, dan kedepannya hurf A berwarna merah tersebut bisa dikolaborasikan dengan desain lain sehingga dapat menjadi ciri khas dari brand Sandpiper. Pemilihan warna monochrome juga dimaksudkan agar logo lebih mudah jika digabungkan dengan warna lain, contohnya jika background warna putih maka bisa digunakan logotype warna hitam, jika menggunakan background warna hitam, logotype bisa dirubah dengan menggunakan warna putih, sehingga terjadi kesan contrast dan pembaca atau konsumen bisa lebih fokus terhadap logotype Sandpiper.

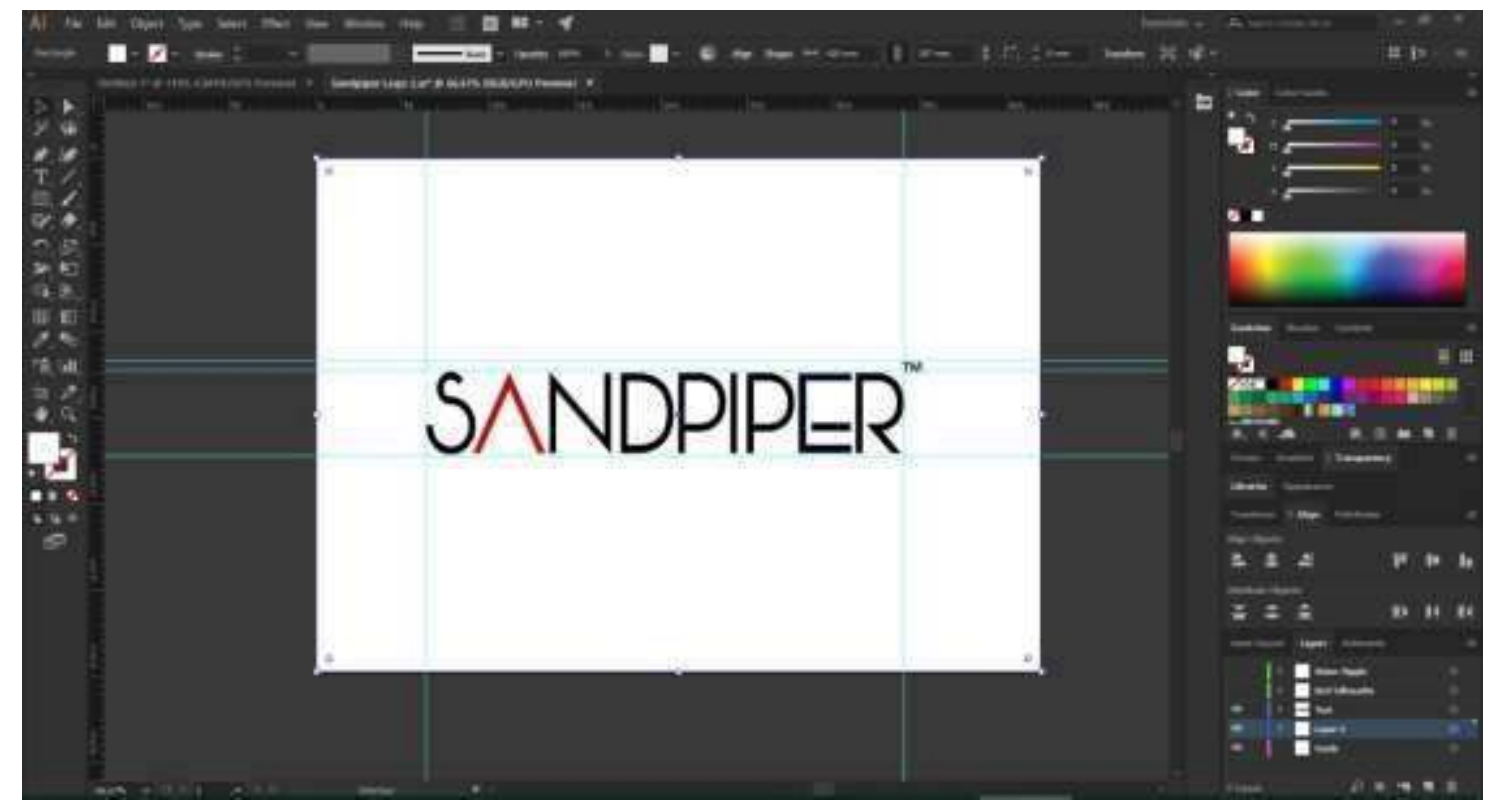




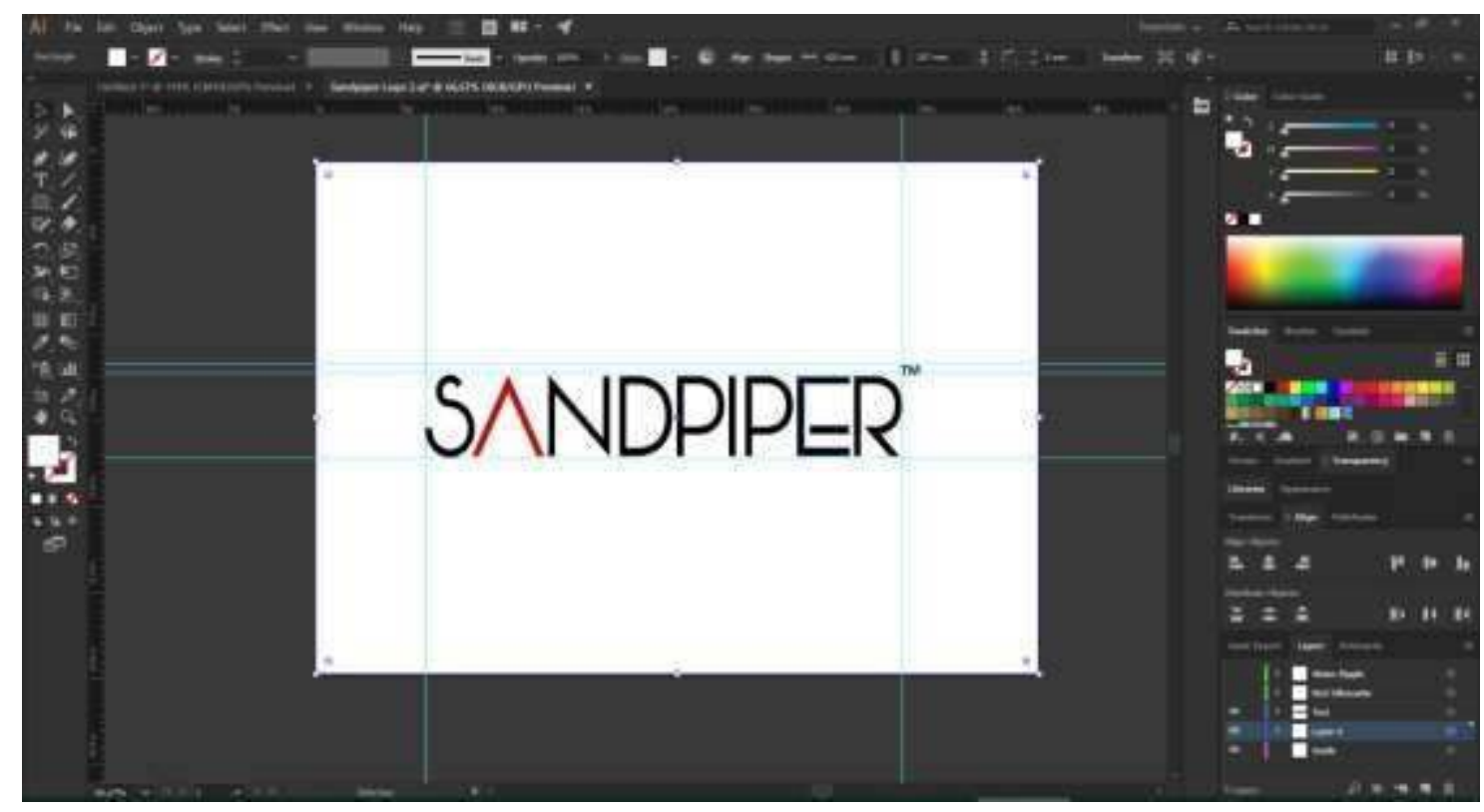

Gambar 2. Gambar Perancangan logotype pada Software Adobe Illustrator

\section{SANDPIPER"}

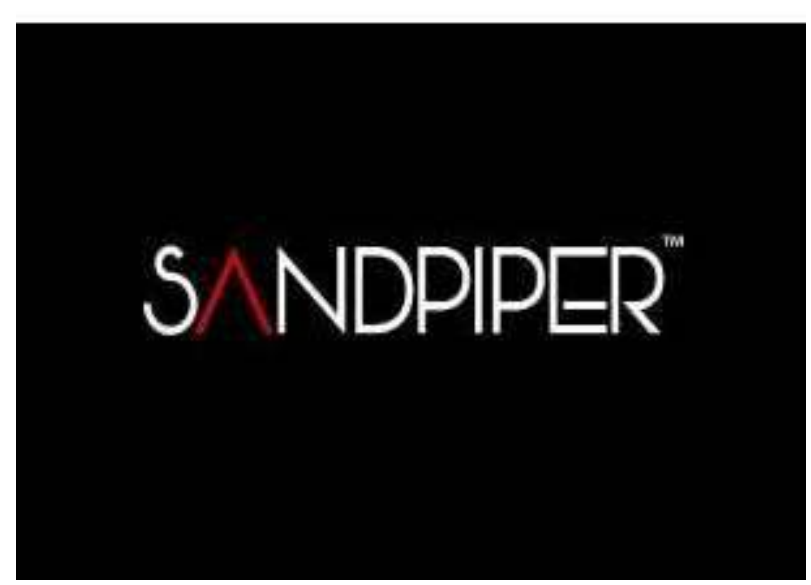

Gambar 3. Gambar Hasil Jadi Logotype Sandpiper dengan menggunakan warna background putih dan hitam.

Dalam pembuatan logotype ini penulis memodifikasi dari font vonique 92, dengan merubah bagian huruf $\mathrm{A}$ dan $\mathrm{E}$ pada font vonique tersebut. 
Warna merah dalam tulisan huruf A menggunakan tipe warna PANTONE + CMYK Coated dengan kode PANTONE 49-8 C. Untuk pewarnaan hitam menggunakan menggunakan tipe warna PANTONE + CMYK Coated dengan kode PANTONE P Process Black $\mathrm{C}$ dan untuk warna putih menggunakan tipe warna PANTONE + CMYK Coated dengan kode PANTONE P 1-1 C.

Warna dipilih karena persepsi warna merah merupakan warna yang memberikan inspirasi power, energy, kehangatan, cinta, nafsu, dan agresi. Warna merah biasanya dapat memicu tingkat emosional seseorang sekaligus warna yang paling sering menarik perhatian. Warna merah memiliki efek untuk menstimulasi sebuah perhatian atau ketercapaian, serta merangsang kelenjar adrenal, hingga meningkatkan detak jantung. Sehingga merah biasa digunakan untuk menarik perhatian.

Warna hitam dipilih karena warna hitam melambangkan ketegasan, profesional, dan kredibilitas sebuah produk.

Warna putih dipilih karena warna ini dapat menyiratkan sesuatu yang bersifat suci, bersih, murni. Pemakaian warna putih dalam logo branding perusahaan juga akan memberi kesan santun. Warna putih akan terlihat kontras dan tegas jika dipadukann dengan warna hitam. Selain itu pula Bentuk-bentuk minimalis dan simpel biasa dilahirkan dengan penggunaan warna ini. Penggunaan warna putih yang digunakan dengan tepat juga mampu memberikan efek keyakinan akan kualitas yang tidak akan mengecewakan.

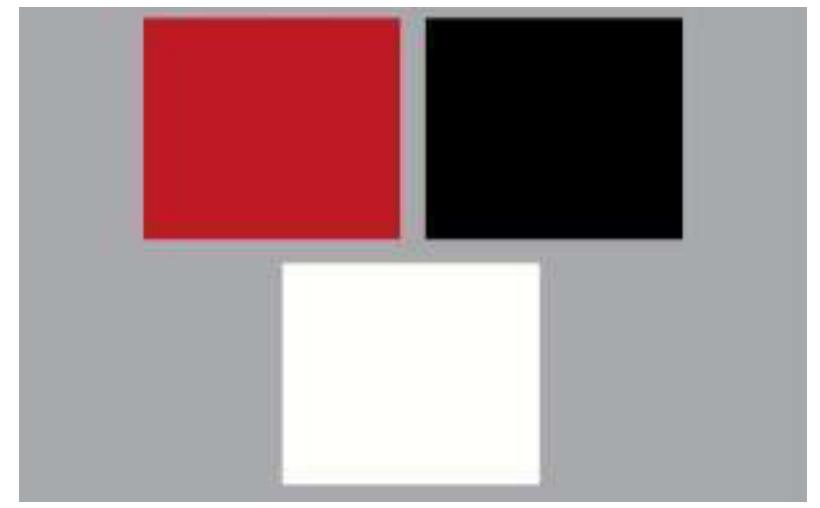

Gambar 4. Warna Dasar Logotype Sandpiper.

Pada bagian logo penulis sengaja memasukan gambar burung yang di manipulasi dengan software agar burung tersebut menjadi silhouette atau hanya bayangan saja. Hal tersebut dilakukan dengan maksud menambah kesan elegan pada logo Sandpiper, selain itu juga logo tersebut mencerminkan informasi produk yang dijual. Sehingga diharapkan para konsumen dapat mengartikan dengan mudah produk dengan kualitas seperti apa yang dijual oleh perusahaan Sandpiper.

Logo burung tersebut juga bisa digunakan sebagai sebuah desain yang berdiri sendiri, sama halnya dengan huruf A pada logotype Sandpiper, sehingga nantinya pada produk yang dihasilkan oleh perusahaan tidak selalu menggunakan logotype saja, tetapi bisa menggunakan desain yang hanya memakai logo, logotype, atau bahkan menggabungkan kedua-duanya. 


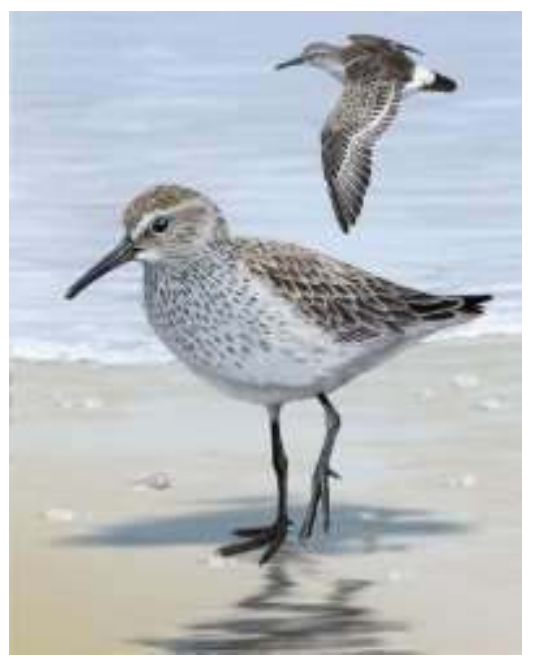

Gambar 5. Bahan Gambar Burung Sandpiper
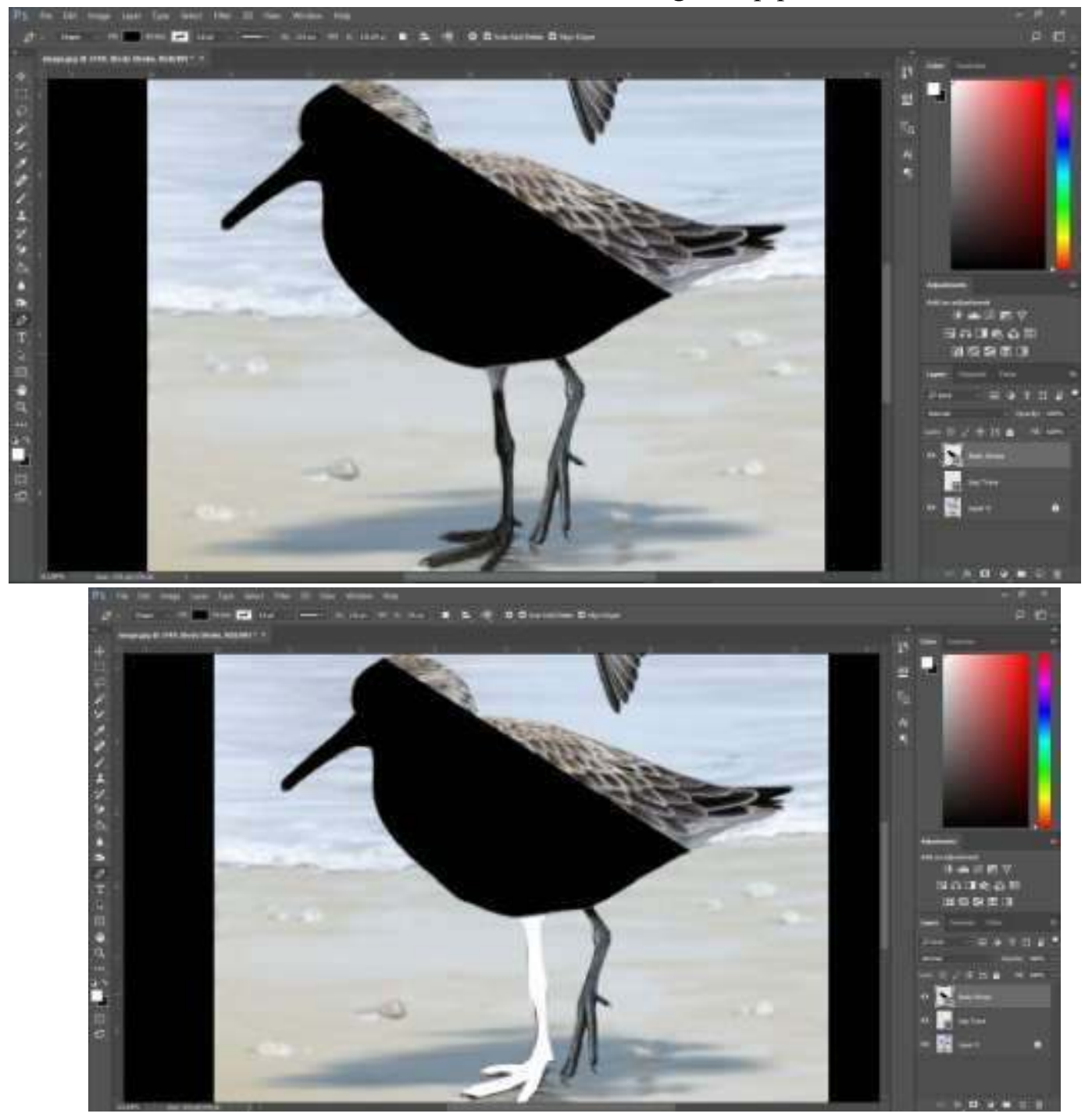


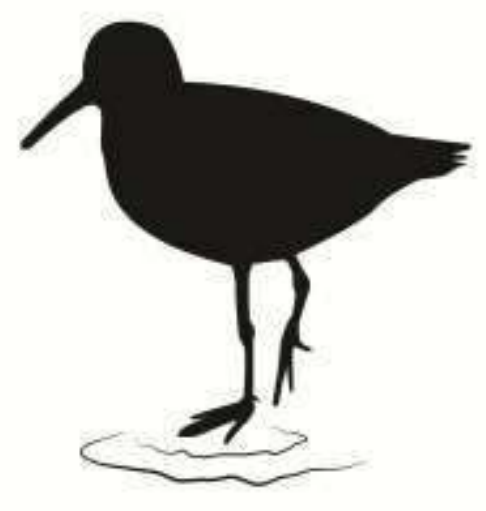

Gambar 6. Manipulasi Gambar Burung Sandpiper menjadi Silhouette.

Dari logo diatas dapat terlihat burung tersebut sedangan berjalan di atas genangan air, hal ini dapat diinterpretasikan bahwa produk sandal yang dibuat oleh perusahaan Sandpiper merupakan sandal yang ringan serta tahan air. Interpretasi diatas sesuai dengan kualitas produk yang dibuat oleh Sandpiper, sehingga logo tersebut bisa merepresentasikan produk yang dijual.

Penggabungan logo dan logotype dapat digunakan selain pada produk, bisa juga digunakan untuk media-media lainnya.

Penerapan logo perusahaan pada media diharapkan dapat meningkatkan citra dari perusahaan atau produk yang dihasilkan serta selain itu juga dapat dijadikan alat promosi. Beberapa contoh media tersebut adalah: Kalender, Logo pada setiap iklan produk baik pada media cetak ataupun media elektronik, pamflet, sticker, neon box advertising, profil perusahaan, Neon Box Ads, Notes, dll.

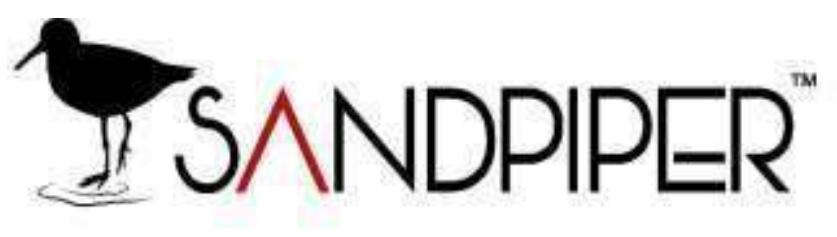

Gambar 7. Logo dan Logotype Sandpiper Putih 


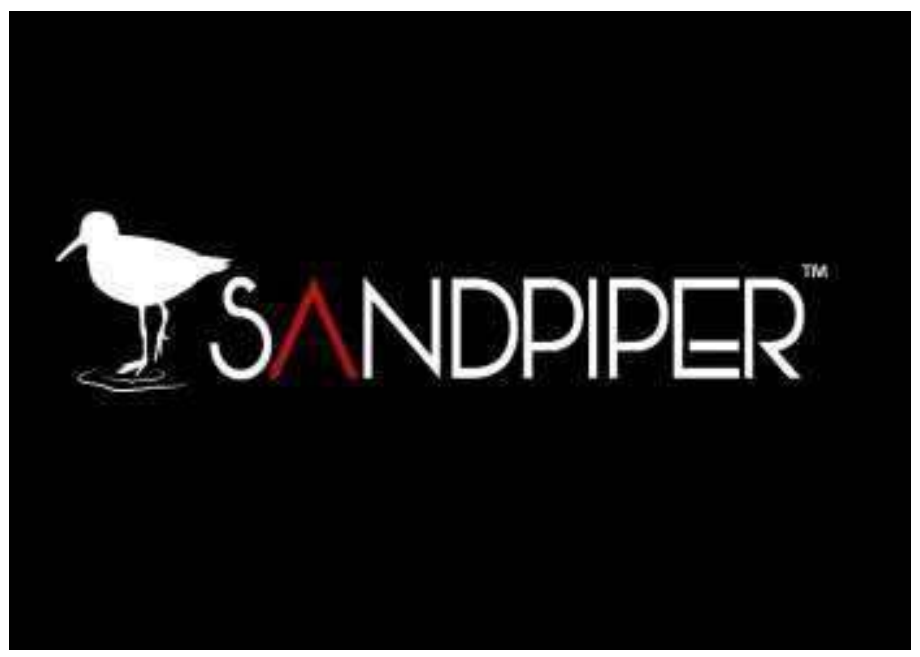

Gambar 8. Logo dan Logotype Sandpiper Hitam

\section{Kesimpulan}

Berdasarkan hasil penelitian penulis, maka penulis dapat simpulkan beberapa keseimpulan, yaitu:

a. Perancangan logo, khususnya logo perusahaan memerlukan konsep yang dapat merepresentasikan perusahaan itu sendiri atau sebagai identitas merek (Brand Identity).

b. Logo dapat menarik perhatian dari pembaca / konsumen serta dapat juga menimbulkan keterikatan emosional.

c. Perancangan ini diharapkan dapat memberikan dampak positif bagi perusahaan Sandpiper sehingga dapat meningkatkan daya saing dengan kompetitor lainnya serta mendongkrak daya jual dari perusahaan.

d. Dengan perancangan ini juga diharapkan brand Sandpiper diharapkan lebih dikenal oleh pasar lokal, nasional, bahkan internasional.

\section{DAFTAR PUSTAKA}

[1] Aaker, J.L. 1997. Dimensions of Brand Personality. Journal of Marketing Research, 34, 347-356.

[2] Aaker, David dan Erich Joachimsthaler. 2000. Brand Leadership. New York: The Free Press

[3] Beatrice Clemetia Halim, Diah Damayanti, Ritzky Karina. 2014. "Pengaruh Brand Identity terhadap Timbulnya Brand Preference dan Repurchase Intention pada Merek Toyota", Vol. 2 ,No.1, 2014, p.3

[4] Durianto, Darmadi, Sugiarto, Tony Sitinjak, 2001, "Menaklukan Pasar Melalui Riset Ekuitas dan Perilaku Merek", Jakarta: Gramedia Pustaka Utama.

[5] Hastjarja. 2005. Upaya membangun ekuitas merek melalui periklanan yang efektif. Journal Manajemen dan Bisnis Vol. 2 Tahun V. P. 62-71

[6] Kotler, Phillip dan Gary Amstrong, 2004, Manajemen Pemasaran Sudut Pandang Asia, PT. Index, Jakarta.

[7] Kotler, Philip dan Keller, Kevin L.. 2006. Manajemen Pemasaran edisi ke 12 Jilid ke 1.New Jersey, Indeks 
[8] Kotler, Philip and Amstrong, Gary. 2011. Principle Of Marketing $14^{\text {th }}$ Edition. New Jersey: Pearson Education, Inc.-Prentice Hall.

[9] Kusrianto, Adi. 2006. Panduan Desain Komunikasi Visual, Elex Media Komputindo, Jakarta.

[10] Rangkuti, F. 2002. The Power of Brands. Jakarta: PT. Gramedia Pustaka Utama.

[11] Rustan, Surianto. 2009. Mendesain Logo. Jakarta: Gramedia

[12] Soehadi, Agus. 2005. Effective Branding: Konsep dan Aplikasi Pengembangan Merek yang Sehat dan Kuat. Bandung: PT. Mizan Pustaka.

[10] Surachman. 2008. Dasar-Dasar Manajemen Merek (Alat Pemasaran Untuk Memenangkan Persaingan). Malang: Bayumedia Publishing.

[11] Tjiptono, Fandy. 2007. Strategi Pemasaran. Andi Offset, Yogyakarta.

[12] Wheeler, Alina. 2006. Designing Brand Identity: A Complete Guide to Creating, Building, and Maintaining Strong Brands. Wiley Publishing. 